\title{
The Liminality of Culture: Second Generation South Asian Canadian Identity and the Potential for Postcolonial Texts
}

\author{
Farha Shariff \\ University of Alberta
}

\begin{abstract}
Canada is in the process of another major shift in its multicultural or pluralist image. Based on the 2006 Statistics Canada census data, onefifth of Canada's population is foreign-born, an immigration surge unprecedented in a quarter century. For the first time in Canadian history, South Asians have become the country's largest visible minority group, making up 25 percent of the nation's visible minorities, making South Asian identity an important issue for English language arts educators to consider when making selections for classroom texts. In this paper, the significance of the second generation of South Asian Canadians with regards to cultural identity is outlined. I highlight the potential for reader response and postcolonial theory as these discourses apply to education and identity studies. Finally, some interview data from a pilot study is presented to bring forth some pertinent identity issues that are of importance to South Asian Canadians today.
\end{abstract}

\section{Beginnings...}

As a second generation South Asian Canadian, I had a hard time growing up. Secondary school was especially difficult, but it was not because I was not a good student. Not unlike other visible minority kids, my "national identity" was constantly questioned-a funny thing for a young adult to have to worry about. I was always asked by teachers, friends, and later on by colleagues: "Are you Canadian?” "Where are you really from?” "You don’t look Canadian.” I often wondered about what it really meant to be "Canadian." I also wondered if my negative association with reading came from my schooling experiences both in and out of the classroom.

When I was in secondary school, I really did not enjoy English language arts. Much of what we read were texts from the canon which had no resonance with my life, with my history, with my cultural values; there was no opportunity to include my own experiences related to what I was reading as they simply did not match. I never felt that I "lost myself" in any of the texts we read. I felt like an outsider to many class discussions and personal responses to texts felt made up; I

Farha Shariff is a second year doctoral student at the University of Alberta in the faculty of Secondary Education in English. She came to the University of Alberta from York University where she completed a master's degree in the area of cross-cultural curriculum studies. 
always struggled to articulate the "right” answer. I was a very strong student and I received very good grades, but I always felt detached from my classroom readings. It was not until I was an adult that I discovered South Asian fiction, and I fell in love with reading. I wished I could have discovered the pleasures of losing myself in a text much earlier in life.

A little context: I am a South Asian woman who has taught in a very "nondiverse” city for a number of years. As an English language arts educator, I felt constant pressure to teach what everyone else in the department was teaching. So I did...for the first few years of my career. I couldn't escape the anxiety around wanting to suggest to my colleagues that perhaps we should introduce more contemporary texts from a wider variety of genres. I did not want to "lose" the few minority students I had in my English classes. I wanted my students to lose themselves in what we read and passionately enjoy responding to texts. I seemed to be the only one who thought teaching the texts $I$ studied 15 years ago seemed to be narrow in scope. I then began to wonder if maybe I had chosen the wrong profession. Why did I seem to question everything about what was being taught in our department, why was it such a big deal to me?

As I began my second year of doctoral studies, I was trying hard to narrow the scope of my research. As I was reading the paper one morning, I came across the most recent results of the 2006 Canadian Census which indicated that Canada's identity as a multicultural nation was changing very rapidly; changes that were indicative of a country that would look very different in the next decade. I wondered if these changes were affecting the way Canadian educators approached the Canadian curriculum. I thought about how the Alberta English language arts curriculum had excluded the experiences of people like me, second generation South Asians Canadians.

Although the choices of texts are wider now than when I was a student, many teachers have had little preparation for working in culturally diverse classrooms and little exposure to existing critiques of multicultural education (Johnston, 2003). Including a "multicultural text" here and there is not enough to "cover" the multicultural "stuff”. However, teachers are often unaware of how race and culture interact to create complex educational and psychological problems for students of visible minority backgrounds. According to theorists Kallin (1994), Delpit (1994), and hooks (1994), teachers may inadvertently make students feel they are invisible and insignificant that their differences are irrelevant through their choice of literary texts. I wanted to know if South Asian students are struggling with cultural identity and how the English language arts curriculum contributed to how students placed themselves in Canadian society.

I propose that reader response theory coupled with postcolonial texts has the potential to offer South Asian students more flexibility and support as they straddle the cultural divide between culture and identity. Some contemporary postcolonial texts suitable for secondary English classrooms could include Haroun and the Sea of Stories by Salman Rushdie (1990), A Group of One by Rachna Gilmore (2001), or the film Bend it Like Beckham, directed by Gurinder Chadha (2002) to name a few. I decided to conduct a pilot study to further investigate the everyday cultural identity experiences of South Asian Canadians. I also was interested in the potential for postcolonial texts to help students to relate, discuss, question, and make sense of cultural identity with what it means 
to be a "hyphenated Canadian." I interviewed four adults to learn more about their lived experiences as South Asians in Canadian schools. What were their schooling experiences? Did they feel Canadian? Could a contemporary postcolonial text, like The Namesake (Lahiri, 2003; Nair 2007), help them understand their racial and cultural identity? This pilot study was intended to probe deeper into how contemporary postcolonial texts could influence and redefine how one might conceive and teach literacies. In particular, how could postcolonial print and media texts help second generation South Asian Canadian secondary students interrogate notions of cultural identity?

In this discussion, I will outline the significance of the second generation as well as briefly describe Canada's history with official multiculturalism. I will also discuss the potential for reader response and postcolonial theory as these discourses apply to education and identity studies, and I finally present some interview data from my pilot study to highlight some pertinent identity issues that are of importance to South Asian Canadians today.

\section{Facing Up to a New Identity?}

Canada is in the process of another major shift in its ever-changing multicultural image. Based on the 2006 Statistics Canada census data, one-in-five people in Canada is foreign-born, an increase of $13.9 \%$ from the previous census, an immigration surge unprecedented in a quarter century. The population of visible minorities is now more than five million (16.2\% of the population, a growth rate five times more than the rest of the population). Moreover, the issue of second generation South Asians is important for the first time in Canadian history when South Asians have become the country's largest visible minority group, making up $25 \%$ of the nation's visible minorities (Gandhi, 2008). Canada's dependence on foreign labour is also attracting many new immigrants who come to Canada to begin a new life. In addition, their children will constitute a large group of second generation youth who will have to negotiate issues pertaining to race, culture, school, and identity.

This unprecedented immigration surge of South Asians comes at a time when the many parts of the country have seen with acts of overt racism that may call into question Canada's reputation for tolerance. By 2030, “Canada's population growth will stem solely from immigration” (Grant, 2007). This surge in immigration is likely to have profound consequences for Canada's educational, cultural, and economic future. It is crucial that educators pay more attention to the issue of cultural identities among second generation Canadian students. Specifically, within the changing demographic of Canadian culture, South Asians have become a visible and integral part of Canada, requiring more attention from educators.

\section{The Second Generation}

It is important to consider the differences between first generation struggles and those struggles of the second generation to understand the notion of identity in postmodern times. Often, many people outside the field of immigration or diaspora studies have different interpretations of the terms "first" and "second" 
generation. The term "second generation" shifts away from the necessary criterion of nativity; the immigrant generation is then, considered to be the first generation South Asian American/Canadian/British rather than erasing this history from the trajectory of the group in the new country. This term also suggests that there is a visible and growing number population of more recent South Asians that do not have the same migration history as South Asian descendants before 1965 (which consisted of highly educated, skilled professionals who, in a relatively short time, acquired middle to upper-middle class status). It must be noted that the term "second generation" also encompasses new immigrants, people in their mid-40s and younger, who have children.

First generation immigrants, often unaware of the significant contrasts between Eastern and Western cultures, discover in the midst of raising their children that there are often conflicting messages their children encounter in the hopes they will fit in, while at the same time staying true to their own cultural ideals. While it is important to represent an integrated view of how immigrants come to make a life in a chosen country, a focus on second generation Canadians is crucial to understanding how South Asians and other new immigrant communities can fit into the economic and social fabric of a Canadian "national identity." The paths followed by second generation individuals who are on the threshold of adulthood_-often associated with occupational/career decisions, the creation of some sort of family unit or independent household, and political/civic participation-will clearly have an impact on the future of larger ethnic communities (Maira, 2002). As Alejandro Portes (1997) observes:

The case for second generation as a "strategic site" is based on two features. First, the long-term effects of immigration for the host society depend less on the fate of first generation immigrants than on their descendants. Patterns of adaptation of the first generation set the stage for what is to come, but issues such as the continuing dominance of English, the growth of a welfare dependent population, the resilience of culturally distinct enclaves, and the decline or growth of ethnic intermarriages will be decided among its children or grandchildren. (p. 814)

\section{A Snag in the Mosaic's Tapestry?}

The process of migration has important implications for defining what it means to be Canadian and, in turn, has equally significant implications for what it means to be South Asian. The changing racial and ethnic composition within Canada's borders has led to much angst and controversy over the definition of Canadian. In a discussion of Canadian and South Asian discourses of cultural protectionism, Amita Handa (2003) suggests:

Second generation youth in Canada are particularly troubling to these discourses because their presence points to the ruptures and contradictions between "modern" and "traditional." Young South Asians struggle to fashion an identity that speaks to their experience of being South Asian in Canada. In doing so, they often unsettle and resist certain mainstream definitions of both South Asian and Canadian. (p. 5) 
The children of the post-1965 wave of immigrants are less visible in the media, not to mention academic literature. Now that second generation Canadians have become adults and created their own social, personal, professional, and familial spaces, their ethnic and national identity development needs to be more adequately researched; this is particularly true of the second generation of South Asian Canadians. Research on second generation identity is timely and significant in light of new research that questions the efficacy of official multiculturalism for the children of visible minority Canadians who exhibit "a more profound sense of exclusion than their parents” (Jimenez 2007).

\section{A State Initiated Enterprise}

Official Canadian multiculturalism developed through the 1970s and 1980s, and had become a major part of Canadian political discourse and electoral organization in the 1990s (Bannerji, 2000). Pierre Trudeau introduced "multiculturalism" in 1971 as a way to encourage newcomers to keep their cultures while adapting to the country's norms. In the new millennium, there is a major shift occurring in the multicultural paradigm of Canada. Will Canada be a truly pluralist country? If the population of immigrants continues to soar (it is estimated that most of the population growth in Canada over the next decade will grow solely from immigration numbers), then the category of second (and perhaps third generation) will also continue to climb, hence adding increasing numbers of visible minorities to Canadian classrooms. From an educational standpoint, one must ask how the cultural identity experiences of second generation South Asian Canadians are manifest in classroom and institutional approaches to literacy? Are Canadian English language arts curriculums changing to meet the needs of the diversity of learners?

Educators must recognize that Canada is in for a facelift. It may seem surprising to some readers to consider that Canadian provincial curricula are still quite Eurocentric in focus and have been based on the inequalities of a class and patriarchal society as well as the inequalities created by racism and colonialism (Johnston, 2003). The historical and formational peculiarities of Canadian curricula cannot be discussed in this paper, but I do focus on the issues surrounding the lived experiences of second generation South Asian Canadian students and what these experiences mean for informing how we think about literary texts in Canadian English language arts classrooms. It is my hope that this discussion will also be of interest to many people of the second generation of many different cultures. Several of the struggles with identity outlined in this paper are also very relevant to a variety of cultures other than "mainstream" dominant culture.

\section{Reader Response and Postcolonial Theories: Possibilities for the Second Generation}

Reader response theory has much to offer the field of identity studies which, in turn, is informed by postcolonial theory. Reader response theorists Wolfgang Iser (1974) and Louise Rosenblatt (1995) suggest that a reader plays a central role in the form of engagement within the reading process: readers live vicariously 
through the text. They encounter their own reality and live out experiences beyond their frame of reference as offered by the text. Likewise, Umberto Eco (1979) describes the "two way" process of reading whereby the reader, bringing his/her own experience to the text, becomes an active contributor to that meaning.

At each reading, the reader generates expectations about the kinds of things that might happen ahead in the text; one anticipates and modifies one's own interpretations of what has been read in light of what one is reading in the presents. The reader's activity is not independent of either textual or cultural constraints, but rather is guided by the text and influenced by personal experience, cultural history, his/her present representation, and the reading conventions s/he has internalized (Rosenblatt, 1995). Iser (1974) argues that literary meaning is not some hidden object or substance that can be extracted from a text; rather it is the text that activates the reader to produce meaning so that literature is an event, something that happens when we read. Therefore, postcolonial texts create the space in which a reader can explore the meanings of their own cultural nuances and experiences alongside the curriculum expectations.

In a general sense, as a literary or critical theory, postcolonial theory examines the interactions between European nations and the societies they colonized in the last few centuries. The field also deals with the impact of colonization on postcolonial history, economy, science, culture, the cultural productions of colonized societies, and feminism (Henry \& Tator, 2006). Postcolonial studies have much to offer Canadian educators, although Canada was not a colonizing power-with the exception of its role in the colonizing of the Indigenous peoples - and was itself colonized. The multicultural nature of Canadian society makes this discourse especially useful because of its emphasis on identity and the processes of changing identity. It can be argued that Edward Said's seminal book, Orientalism (1978) is one of the foundational works of the field, followed by today's most expressive postcolonial scholars, Homi Bhabha (1990). Bhabha coined the term "hybrid" to describe persons who are in a "liminal state," between two cultures, and whose culture and behaviour is neither one nor the other. Such can be said of the second generation of South Asian Canadians who walk the tightrope of culture. For example, the findings of my study suggest that on one hand, the participants were constantly positioned in relation to race and racial difference, and on the other hand, liberal discourses of multiculturalism reinforce the notion of racial equality. The difficulty for South Asians then becomes naming experiences of racism within a context that constantly tells tem that race and racial difference do not matter. A tension exists between sameness and difference that is connected to discourses of difference and retention of binary categories that obscure the dynamics of inequality (Handa, 2003). South Asians become "othered” by a dominant culture which categorizes them as "visible minorities," "ethnics," immigrants, or foreigners. These categories are considered to be incommensurable with being a "real" Canadian despite the promises of multiculturalism. The second generations of South Asian Canadians are never quite Asian enough nor are they quite white enough; they exist in a liminal space. 
Although it can be argued that postcolonial literature is hardly a new form of literacy, it certainly has the potential to create a new ethos or way for people to be in the world and, thus, fundamentally shift how they create and understand literacies. Postcolonial literature has played an important role in the ways in which colonialism has influenced the perceptual frameworks of people living in the world today (Dimitriadis \& McCarthy, 2001). Literature on postcolonial literary theory and critical multiculturalism reveals that the connection between literature and the students' cultural world needs to be further explored (Bhabha, 1994; Giroux, 1992; Dimitriadis \& McCarthy, 2001). Postcolonial literary theories offer critical transdisciplinary interpretations of the human condition and, therefore, have significant implications for curriculum and educational practices that are challenged by the strength of diversity and cultural change. These literature on postcolonial literary theory and critical multiculturalism questions the essentializing project of English literature study by addressing ongoing issues pertaining to the continued use of the western literary canon, helping to negotiate the worlds of establishment aesthetics and popular/vernacular culture.

Postcolonial texts enable students to negotiate cultural identity formation amongst the complex bicultural existence of growing up as "Canadians of visible minority" by addressing issues of identity, power, race, and gender. The study of English has always been a heavily political and cultural phenomenon, a practice in which language and literature have both been called into the service of a profound and embracing nationalism. Ingrid Johnston (2003) offers us ways to think about the importance of using postcolonial texts in the secondary English classroom. Teachers are encouraged to develop a practice of postcolonial pedagogy that will guide teachers and students to see the world through different lenses. Postcolonial material and teaching strategies geared towards critical thinking provide students with opportunities to consider the significance and historical past in helping to shape their lives. Students have the opportunity to look outward and to see ambivalences in their own cultural heritages and intersections between their own lives and those of others (Johnston, 2003).

\section{The Study}

The findings presented in this article were drawn from my work with four second generation South Asian Canadians, both male and female between 25-35 years of age. The data presented in this paper describe the experiences of second generation South Asian Canadians as they respond to a contemporary postcolonial text, The Namesake (Nair, 2007), which explores the importance of names and naming practices. The title reflects the struggles of the South Asian American protagonist, Gogol Ganguli, and what he goes through to identify with his unusual name. The film centers on second generation identity, the complications of growing up between Eastern and Western cultures, ethnic identity, and intergenerational/cultural differences. Both males (Oz and Sam) and one female participant (Sanam) came from small, middle to upper class suburbs of a larger city in central Alberta with a predominantly white population. The other female (Saira) was born in Arusha, Tanzania and immigrated to Canada at the age of 5 . All 4 participants were well-educated, post-graduate students and 
young professionals whom I contacted through professional organizations and acquaintances. My respondents came from families that represented earlier waves of post-1965 Pakistani and Ugandan immigrants who are both were also welleducated, upper-middle class professionals.

During the data analysis, I was aware that the narratives may have been influenced by my gender, ethnicity and by own history as a second generation South Asian Canadian. I was well aware that the respondents may present ethnic identifications partially in response to the context of the interview, the questions, their relationship to the interviewer, and the way the questions are formulated. Understanding my research interests in relation to my race, culture, gender, history, and social class place me in a space where my subjectivity gives meaning to the objective nature of the research.

From the very beginning of The Namesake, the issue of names and the link to identity is apparent to the viewer and chronicles Gogol Ganguli's cross-cultural experiences through the rejection and the subsequent exploration of his Indian culture; the disavowal of his name is used as an extended metaphor throughout the film to explore larger issues of integration, assimilation, and cultural identity. The name "Gogol” only fills the young American, soon to be faced with several identity crises, with dissonance and shame, infiltrating his entire life. The participants of this pilot study also discussed similar complexities with the issue of having an ethnic name. One male participant answered:

Officially, I have 5 names. If you were to ask me why I have so many names, why I have two last names, or which names are on my birth certificate, I would be hard pressed to answer honestly. My first name has been the most awkward for me. The name is not the easiest word for English speaking Canadians to pronounce phonetically and causes me to become somewhat anxious when introducing myself to new friends or colleagues. It can get somewhat irritating spelling your name out every time you meet someone new.

\section{$\mathrm{Oz}$}

Throughout his life, Oz struggled with the "uniqueness" of his name. However, in South Asian culture, names are considered to be of great importance and should be something to be proud of; "individual names are sacred, inviolable. They are not meant to be inherited or shared” (Lahiri, 2003, p.28); they are something special. However, like Gogol, Oz expressed that much of his adolescence was spent embarrassed by his name and culture and tried his best to reject all things “Indian.” Growing up in a western society where children are often ashamed of their differences, Oz wanted to just blend in and live unnoticed. By discussing his own struggles with growing up with an "ethnic" name alongside those of the protagonist, this he "came alive" when describing how he, too, went through many difficult times growing up “different”. He had many stories to tell about his struggle with an ethnic name in a Western society, which also translated to additional struggles well into adulthood. When discussing how 
he felt about his name during the interview process for medical school, Oz expressed anxiety about being introduced by or introducing himself to others.

People would sometimes not make an effort to learn my name; it becomes a barrier and makes it somewhat difficult to evaluate me out of a hundred others when they can't put a name to the face.

$\mathrm{Oz}$

Another male participant reflected similar frustrations with how his name was received by others.

Growing up it was bothersome to a point, but after a while, I never cared, because no matter how often I would correct people, they still would screw up a three letter name.

Sam

Both male participants struggled to varying degrees, with how their names were received by their dominant white peer groups and social groups. Both males indicated however, that their names had special significance and subsequently had an impact on how they saw themselves in relation to their cultural and religious understandings of identity. They also indicated how helpful and cathartic it would have been to identify with characters like Gogol, as they moved through high school. As reader response posits, there should be a focus on the reader and his/her creative and imaginative activity in constructing meaning under the guidance of the text; meaning has no existence outside the mind of the reader who interprets the text in light of his/her own experiences and values. If a reader's experiences with culture, history and values are not represented in any of the texts they read there is the potential for a disconnect and detached stance to texts studied in the English language arts classroom. One of the female participants also alluded to difficulties with names growing up in Canada.

Often, we are prejudged by our names. In part, our names define us to the world and in turn we may or may not identify with our name.

\section{Saira}

Not only are first introductions a source of anxiety, but as both female respondents indicated, names have an intimate connection with identity in relation to the Western/Canadian gaze. When the cultural, social, and public practices of the dominant culture intersect with South Asian culture and specifically with the significance or the rejection of a name, it is evident that there is a cultural conflict between how a second generation individuals perceive themselves to be and how they are perceived by others. In an effort to find a more congruous blend with the dominant society, second generation South Asian Canadians must deal with the mispronunciation of their names as well as having their names Anglicized. The participants discussed at length the implications of 
their names and the impact names have on identity. They pointed to the coping practices that were used that had influential consequences upon their identities.

\begin{abstract}
Having an uncommon, name in society, we often find ourselves changing the true pronunciation, modifying the name thereby changing its meaning and ultimately changing how we define ourselves to society. I believe this is where we run the risk of disconnecting with our true identity and being comfortable with who we are and where we come from. It's often ignorance that forces us to do so.
\end{abstract}

Sam

South Asains may come to identify with a name early in life and, thus, may prefer this daak naam, or nick name to our proper name if it is more convenient for a particular context or situation. Conversely, it may have negative effects on how they see themselves.

I went through a period of 7 years (teens through to early adulthood) where I used a different name in the workplace, initially given to me by a co-worker who just could not pronounce my name. I adopted this nick-name in and I believe it affected how I saw myself, how others saw me and how I interacted with people around me. I finally decided at the age of 22 to go back to using my real given name and as a result began to feel like I was once again my true self.

\title{
Saira
}

Adolescence is commonly known as a time of peer identification when educational institutions place children together by age. Situational and cognitive factors, for example, during adolescence can create a disconnect and shift in the identification with an ethnic name. Many South Asians experience dissonant and conflicting feelings associated with trying to negotiate multiple identities that are dependent on situational factors. The struggles of second generation South Asians to define themselves in the contexts of family and two diverse cultures throughout early adolescence and well into adulthood are evident in the narratives of the participants.

Like Gogol, I believe that part of my ability to make friends in High School and University was my ability to properly assimilate in many ways to Canadian culture; with dress, sports, music, and relationships, I was able to somehow create a Canadian personality in Indian skin. While I know that this was merely a product of my surroundings, I could see those who did not assimilate as well get shunned and actively teased by our peers for their accent, dress, etc. 
$\mathrm{Oz}$

Slavoj Žižek (1992) discusses the difference between how we see ourselves and how others see us as the difference between the "imaginary" and the "symbolic." In "imaginary" identification, we imitate the other at the level of resemblance, identifying ourselves with the image of the Other. This is precisely why South Asians identify more with an Anglicized nickname. In "symbolic" identification, South Asians identify themselves with the Other "at precisely the point at which he is inimitable; the point which eludes resemblance" (Žižek , p. 109). A decision to change their name, in effect, is their effort to resemble the $\mathrm{I}(\mathrm{O})$ or Lacan's notion of the ego-ideal. In this instance, the $\mathrm{I}(\mathrm{O})$ is the Canadian/American/Brit who speaks without an accent, who does not smell Indian, who does not act Indian, ultimately rejecting the symbolic order of our South Asian culture. The two identities of "the Canadian" self and "the South Asian" self are at odds, opposite, conflicting, self-hating, and indicative of the various schemas South Asian youth must negotiate between, allowing a glimpse into the split between who they think they are and they want to be as well as who they are really struggling to become.

Participants were also asked to discuss what details made the characters realistic and what details reminded them of their own story growing up between cultures. The participants commented on how the film related to their own experiences of growing up as a second generation South Asian.

I felt guilty for not embracing my culture more and angry at Canadian culture and school system for the pressures it put on me as a child to repress any sort of culture I had. My parents did not encourage us to learn their mother tongue out of fear we would develop accents and be teased at school or have lesser opportunities at success in the workplace.

$\mathrm{Oz}$

I knew that my cultural heritage was important, but I wanted to embrace being a Canadian more, therefore thinking some traditions were stupid or old.

\section{Sam}

Reflective of the different struggles of growing up between cultures, the participant responses are helpful for educators to see how difficult the negotiation of culture, identity, and schooling can be for bicultural adolescents who "live at the juncture of two cultures and can lay claim to belonging to both cultures" (Lafromboise, Coleman, \& Gerton, 1993, p. 4). This exploration helps educators to consider how identity acts as key site for narrative (re-)constructions and points to the various ways that postcolonial texts, media, and film can act as 
particularly relevant producers of public narratives of individual or collective identities.

Theoretically, there is a homology in the conceptualizations of memory, identity, and media experiences. According to Brigitte Hipfl (1995), all three of these conceptualizations are defined by provisional and continuous processes; they are negotiated and modified in the light of experiences of the present. At the same time, these three concepts complement each other because of the different aspects being elaborated. In the case of the participants' engagement with the film, their experiences reflect a deepening of their understanding of the complex and contradictory ways in which media are of relevance for their constructions of second generation South Asian identity. Roland Barthe (1970) conceded that there are certain codes that readers have learned from their experiences of living in society and reading literature. The codes are shared by both author and reader to create a kind of network through which a text passes to become a literary work. Readers construct a work of literature out of text by filtering the text through the network of codes they have internalized. These codes recognize the importance of readers' life experiences to literary understanding. As Iser (1974) notes, the reader's activity is not independent of either textual or cultural constraints, but is guided by the text and influenced by personal experience and cultural history, his/her present meaning and the reading conventions s/he has internalized.

Currently, there is little research that explores the experiences of second generation South Asian Canadian students and what they understand about what it means to grow up Canadian. This discussion will contribute to ongoing debates about teachers' continued dependence on the literary canon in contemporary secondary classrooms and question the potential for the use of more contemporary postcolonial texts in the English language arts classroom.

The recent increases in South Asian immigrants to Canada make it crucial that educators pay attention to the experiences of second generation South Asian Canadian adolescents and examine the relationships between literacy and an evolving sense of national identity. There is, in fact, little Canadian research that addresses the experiences of second generation South Asian adolescents as a bicultural population in relation to in-school reading and viewing literacy practices. The findings of this pilot study suggest that South Asian identity is an issue that many second generation South Asian Canadian youth struggle with. There is also need for a more critical understanding of a liminal notion of identity as negotiated by second generation South Asians to better understand their identity struggles and the implications of these struggles for literacy activities and text selection in English language arts classrooms. As reflected in the participant responses to the identity and assimilation struggles of second generation South Asians as presented in The Namesake (2007), it is evident there are difficulties for second generation South Asian Canadians in straddling the cultural and racial divide between white/non-white categories.

These stories of the participants in this study point to the existence of a recreation and a renewal of cultural traditions with Canadian culture in the second generation. The notions of cultural authenticity in relation to hierarchies of race, class, gender, and national identity that mark this generation as "Canadian” are important to consider. Several second generation youth of 
various cultures explore their ethnic identities as young adults due to the circumstance of being slightly detached from family culture and, in many cases this is because of a Eurocentric school education. South Asian youth are not able to take cultural assumptions for granted and, therefore, find it difficult to "blend" into dominant society. By focusing only on the "hybridization" of Western with Eastern cultural elements, such as music, film or text, the term "hybrid" does not fully capture the complexities of racial ideology and class expectations that South Asian youth negotiate in their daily lives.

As per the participants' interviews, there is prevalence among second generation Canadians as being self-conscious about the hybrid nature of their experiences as children of immigrants. With this exploration comes the reflexivity inherent in the participation in anything related to another culture $\mathrm{t}$ outside the home environment. Contemporary postcolonial texts have the potential for creating a space to begin the complicated conversations around what it means to belong to a national identity, a conversation that is yet to be adequately researched. Despite a growing acknowledgement that we should be mindful of cultural pluralism and consider students' diverse ethnic, cultural, and linguistic backgrounds in choices for classroom texts, there is still a need to reconceptualize literacy for the changing faces of our contemporary Canadian classrooms.

\section{References}

Ashcroft, B., Griffiths, G., \& Tiffin, H. (2004). The empire writes back: Theory and practice in postcolonial literatures. New York: Routledge.

Bannerji, H. (2000). The dark side of the nation: Essays on multiculturalism, nationalism and gender. Toronto: Canadian Scholars' Press Inc.

Bhabha, H. (1994). The location of culture. London: New York: Routledge.

Britzman, D., \& Pitt, A. (2003). Speculations on qualities of difficult knowledge in teaching and learning: An experiment in psychoanalytic research. Qualitative Studies in Education, 16, 755776.

Britzman, D. (1998). Lost subjects, contested objects: Toward a psychoanalytic inquiry of learning. Albany, NY: State University of New York Press.

Britzman, D. P. (1992). "The terrible problem of knowing thyself: Toward a poststructural account of teacher identity." JCT: An Interdisciplinary Journal of Curriculum Studies, 9(3), 23-46.

Chadha, G (Director \& Writer), Bindra, G. (Writer). (2002). Bend it like Beckham [Motion Picture]. United States: Fox Searchlight Pictures.

Cherland, M. R. (1994). Private practices: Girls reading fiction and constructing identity. London: Taylor \& Francis.

Delpit, L. (1994). Other people's children. New York: Routledge.

Dimitriadis, G., \& McCarthy, C. (2001). Reading and teaching the postcolonial from Baldwin to Basquiat and beyond. New York: Teachers College Press.

Eco, U. (1979). The role of the reader. London: Penguin.

Gandhi, U. (2008, April 8). Facing up to a new identity. The Globe and Mail. Retrieved April 8, 2008, from http://www.theglobeandmail.com/

Gilmore, R. (2003). A Group of One. Canada: H.P. Fenn.

Giroux, H. (1992). Border crossings: Cultural workers and the politics of education. New York: Routledge.

Grant, T. (2007, December 4). “Foreign-born population hits 75 year high.” The Globe and Mail. Retrieved Dec 04, 2007, from http://www.theglobeandmail.com

Grumet, M. (1999). Autobiography and reconceptualization. In W.F. Pinar (Ed), Contemporary curriculum discourses: twenty years of JCT. New York: Peter Lang. 
Handa, A. (2003). Of silk saris and mini-skirts: South Asian girls walk the tightrope of culture. Toronto: Women's Press.

Henry, F., \& Tator, C. (2006) The colour of democracy: Racism in Canadian society. Toronto: Nelson.

Hipfl, B. (1995). Memory work—Narrating media experiences. Retrieved Oct 7, 2007, http://www.google.com/search?q=cache:LB7Esb kh7QJ:web.mit.edu/commforum/mit4/papers/hipfl.pdf+amelie+hipfl\&hl=en\&ct=clnk\&cd=1\&gl=ca

Holcombe, G. (2004). Salman Rushdie: Biography. retrieved April 15, 2007 from Contemporary Writers in the UK, British Council website: http://www.contemporarywriters.com/authors/

hooks, b. (1994). Teaching to transgress: Education as the practice of freedom. New York: Routledge.

Iser, W. (1974). The implied reader. London: John Hopkins University Press.

Jiminez, M. (2007, January 12). How Canadian are you? The Globe and Mail. Retrieved January 12, 2007, from http://www.theglobeandmail.com/

Johnston, I. (2003). Re-mapping literary worlds: Postcolonial pedagogy in practice. New York: Peter Lang.

Kallin, J. (1994). Anti-racist staff development for teachers: Considerations for race, class, and gender. Teacher and Teacher Education, 10(2), 169-184.

Lafromboise, T., Coleman, H. L. K., \& Gerton, J. (1993). Psychological impact of biculturalism: Evidence and theory. Psychological Bulletin, 114, 395-412.

Lahiri, J. (2003). The namesake. USA: Houghton Mifflin.

Maira, S. (1996, April). Ethnic identity development of second generation Indian American adolescents. Paper presented at the Annual Meeting of the American Educational Research Association, New York, NY.

Maira, S. (2002). Desis in the house: Indian American youth culture in New York City. USA: Temple University Press.

Nair, M. (Director) \& Taraporevala, S. (Writer). (2007). The Namesake [Motion Picture]. United States: Fox Searchlight Pictures.

Portes, A. (1997). Immigration theory for a new century: Some problems and opportunities. International Migration Review. 31(4), 799-825.

Rosenblatt, L. (1995). Literature as exploration. New York: Modern Language Association of America.

Rushdie, S. (1991). Imaginary Homelands. Essays and Criticisms 1981-1991. New York: Viking and Granta

Rushdie, S. (1990). Haroun and the Sea of Stories. New York: Penguin Books and Granta.

Taubman, P. (2007). "The beautiful soul of teaching: The contribution of psychoanalytic thought to critical self reflection and reflective practice.” In M. Gordon and T. O’Brien (Eds.), Bridging the Gap between Theory and Practice. (pp. 1-17.) Rotterdam, Netherlands: Sense Publishers.

Taubman, P. (2000). Teaching without hope. Journal of Curriculum Theorizing, 16(3), 19-33.

Žižek, S. (1992). The sublime object of ideology. United Kingdom: Verso.

Žižek, S., \& Daly, G. (2004). Conversations with Žižek. United Kingdom: Polity Press. 